\title{
Microbial diversity in various types of paper mill sludge: identification of enzyme activities with potential industrial applications
}

\author{
Manel Ghribi ${ }^{1,2}$, Fatma Meddeb-Mouelhi ${ }^{1,2}$ and Marc Beauregard ${ }^{1,2^{*}}$ (D)
}

\begin{abstract}
This study is the first comprehensive investigation of enzyme-producing bacteria isolated from four sludge samples (primary, secondary, press and machine) collected in a Kraft paper mill. Overall, 41 strains encompassing 11 different genera were identified by $16 \mathrm{~S}$ rRNA gene analysis and biochemical testing. Both biodiversity and enzymatic activities were correlated with sludge composition. Press sludge hosted the largest variety of bacterial strains and enzymatic activities, which included hydrolytic enzymes and ligninolytic enzymes. In contrast, strains isolated from secondary sludge were devoid of several enzymatic activities. Most strains were found to metabolize Kraft liquor at its alkaline pH and to decolorize industrial lignin-mimicking dyes. Resistance to lignin or the ability to metabolize this substrate is a prerequisite to survival in any paper mill sludge type. We demonstrate here that the bacterial strains found in a typical Kraft paper mill represent a source of potential novel enzymes for both industrial applications and bioremediation.
\end{abstract}

Keywords: Bacteria, Enzymes, Bioplastic, Pulping liquors, Dyes

\section{Background}

Industrial enzymes are at the heart of green chemistry as illustrated by a global market value that reached $5 \mathrm{G} \$$ in 2013 which is expected to climb to $7 \mathrm{G} \$$ by 2018 , a compound annual growth rate of $8.2 \%$ over 5 years (Global Markets for Enzymes in Industrial Applications; Nigam and Pandey 2009). While all living organism produce enzymes, microorganisms have been and are increasingly being used as cell factory for enzyme production, and as a source for various chemicals (therapeutics, bioethanol and bioplastics to name few) (Adrio and Demain 2005; Ai et al. 2003; Charbonneau et al. 2011; Demain and Adrio 2008; Paye et al. 2015; Rehman et al. 2007). Currently, most industrial enzymes originate from microorganisms like Bacillus, Aspergillus and Trichoderma (Apparao and Krishnaswamy 2015; Arora and Sandhu 1985; Bengtsson et al. 2006; Demain and Adrio 2008; Kubicek et al. 2001;

\footnotetext{
*Correspondence: marc.beauregard@uqtr.ca

${ }^{1}$ CRML, Centre de Recherche sur les Matériaux Lignocellulosiques, Université du Québec à Trois-Rivières, C.P. 500, Trois-Rivières, QC G9A 5H7, Canada

Full list of author information is available at the end of the article
}

Liu et al. 2013; Pandey et al. 1999). These biocatalysts have found applications in various fields that depend on hydrolytic, ligninolytic and biosynthetic processes, to name a few (Barr and Steven 1994; Braunegg et al. 2004; Chandra et al. 2011; Martínez et al. 2005; Nigam 2013).

Hydrolases (or hydrolytic enzymes) are the largest group of enzymes on the market and are used in detergents, pharmaceuticals, therapeutics, textiles, baking, biofuel and pulp and paper (Bengtsson et al. 2006; Crecchio et al. 1995; Eriksson and Kirk 1994; Kirk et al. 2002). Hydrolases include carboxyl ester hydrolases (lipases, esterases), glycosylases (cellulases, xylanases and amylases) and proteases that hydrolyze lipids, sugar polymers and proteins, respectively. Application of ligninolytic enzymes [lignin peroxidase (LiP), manganese peroxidase $(\mathrm{MnP})$ and laccase $(\mathrm{Lac})]$ is a growing sector of industrial enzymology. In recent years ligninolytic enzymes have been shown to be effective in industrial applications, including bio-remediation, pollution control and treatment of industrial effluents containing recalcitrant and hazardous chemicals such as textile dyes and or lignin mimicking dyes, phenols and other xenobiotic 
(Bandounas et al. 2011; Brahimi Horn et al. 1992; Chandra et al. 2011). This group of enzymes is also used in the pulp and paper industry for pre-treatment of wood pulp, for bio-bleaching and bio-pulping (Eriksson and Kirk 1994; Huang et al. 2007).

In addition to their use as enzyme production factories, microorganisms have attracted a growing interest for their biosynthetic pathways, including those leading to the synthesis of biodegradable plastics, such as polyhydroxyalkanoates (PHAs) (Singh et al. 2009; Verlinden et al. 2007). PHA polymer is synthesized and accumulated by bacteria as means for storing carbon and energy during unbalanced growth conditions (Chen 2009). Applications for PHA have been developed in various fields such as bioplastics, fine chemicals, implant biomaterials, medicines and biofuels (Gomaa 2014; Nathalie et al. 2015).

Screening bacteria for industrially useful enzymes is now a key endeavor in industrial biotechnology. Bacteria and bacterial enzymes are becoming much more important for the treatment of lignocellulosic materials, as some outperforming commercial fungal extracts for the hydrolysis of cellulose and hemicellulose fibers (Hardiman et al. 2010; Maki et al. 2011; Singh and Prabhu 1986; Zhou and Ingram 2000). Bacteria generally inhabit ecological niches characterized by specific attributes such as $\mathrm{pH}$, temperature, specific carbon or substrate availability, presence of salt and other chemical factors (solvent, inhibitors, toxicants, oxygen, etc.). Such attributes determine the array of enzymes and metabolic routes necessary for survival and are an important aspect of screening. In our laboratory we have taken advantage of this relationship between enzymes and niche attributes for identification of novel strains and enzymes from compost (Charbonneau et al. 2011).

The wastewaters or sludge generated from paper making processes are enriched with various fiber wood compounds such as lignin, carbohydrate polymers (cellulose and hemicellulose) and other extractives (lipids and others) in addition to some potentially toxic compounds such as chlorinated organics, resin acids, heavy metals and others (Abhay et al. 2007; CANMET Energy Technology Centre 2005; Karn et al. 2010; Kuhad et al. 1997). The sludge environments could be effective incubators of a wide variety of resistant, adapted bacteria and should offer an ideal source of enzymes suitable for related industrial applications. Consequently, investigations on paper mill sludge microflora have been previously reported. Studies by Maki et al. (2011), Karn et al. $(2013,2010)$, and Desjardins and Beaulieu (2003) showed that paper mill sludge is a great incubator and host for a variety of microorganisms. Such studies have focused on a precise type of process, used a single sludge type, focused on one particular enzyme, and revealed limited information on sludge microflora. Various types of sludge are produced at different steps along the paper making process, in order to manage waste effluents. To our knowledge, the biodiversity of individual sludge types found in a Kraft paper mill has yet to be studied. Here, we report an exhaustive characterization of the microflora existing in three types of paper mill sludge and one environmental sample obtained from an Eastern Canadian Kraft paper mill. We established a screening for a wide range of extracellular enzymes produced by bacteria found in these sludge samples. We also identified bacterial strains that have various potential applications in pulp and paper, pollution control, bioremediation and bioplastic production. Sludge sampled at different production stages revealed important differences in bacterial strains and enzyme production despite being sampled at the same facility.

\section{Methods}

\section{Paper mill sludge sampling and characteristics}

Four sludge samples were collected from a paper mill at Trois-Rivières (Québec, Canada). Samples were collected in plastic bags under aseptic conditions and marked according to their source and location. The temperature was measured on site of collection. The collected samples were transported to the laboratory for the isolation of sludge bacteria. All sludge samples were stored at $4{ }^{\circ} \mathrm{C}$, used and processed within $48 \mathrm{~h}$. Sludge descriptions and characteristics were reported in Table 1.

Primary sludge (IS) recovered at the first step of clarification is usually obtained by sedimentation. IS sludge is dark brown in color, having a $\mathrm{pH}$ and temperature of 7.2 and $37{ }^{\circ} \mathrm{C}$ respectively. The secondary sludge (IIS) is generated in the clarifier of the biological unit used for wastewater treatment. IIS volumes are lower than those corresponding to the primary sludge, since most of the heavy, fibrous or inorganic solids are removed in the primary clarifier (CANMET Energy Technology Centre 2005; Integrated Pollution Prevention and Control (IPPC) 2001). IIS temperature and $\mathrm{pH}$ are slightly less than found in IS. Press sludge (PS) is a mixture of primary sludge and secondary sludge following acid treatment, and its $\mathrm{pH}$ and temperature are around 3 and $30^{\circ} \mathrm{C}$ respectively. PS is the richest in carbonic matter due to the fact it is a concentrated mixture of two different kinds of sludges (primary and secondary). An additional sample used for this study was an environmental sample collected from organic deposits (dirt) around paper mill machines (MS). This sludge was light brown, had a neutral $\mathrm{pH}$ and was of moderate temperature (ambient to few degrees above ambient temperature). 
Table 1 Paper mill's sludge characteristics

\begin{tabular}{|c|c|c|c|c|}
\hline Sample & Origin & Color & $\mathrm{pH}$ & $\mathrm{T}^{\circ} \mathrm{C}$ \\
\hline Primary sludge (IS) & Discharges from pulp processing which are rich in cellulose-fiber and undergo settling, solid state & Dark brown & 7.2 & 37 \\
\hline Secondary sludge (IIS) & Decantation of primary sludge, undergo another physical settling, solid state & Dark brown & 7.0 & 30 \\
\hline Press sludge (PS) & Mixture of secondary and primary sludge, solid state & Dark brown & 3.0 & 35 \\
\hline Machine samples (MS) & Environmental samples found around machine in the mill, solid state & Light brown & 7.2 & 37 \\
\hline
\end{tabular}

\section{Isolation and growth of bacteria from sludge samples}

To isolate the bacteria contained within each sludge sample, a $1.0 \mathrm{~g}$ sub-sample was diluted in $100 \mathrm{ml}$ of saline $(0.85 \% \mathrm{NaCl})$, thoroughly mixed by vortexing, and incubated for $1 \mathrm{~h}$ at $50{ }^{\circ} \mathrm{C}$. After which the solution was filtered through a sterile filter paper to remove all solids. A $200 \mu \mathrm{l}$ volume of filtrate from each sludge sample was spread on minimum media $(\mathrm{Mm})$ agar plate $(0.1 \%$ $\mathrm{NaNO}_{3}, 0.1 \% \mathrm{~K}_{2} \mathrm{HPO}_{4}, 0.05 \% \mathrm{MgSO}_{4}, 0.1 \% \mathrm{KCl}, 0.05 \%$ yeast extract and $1.5 \%$ Bacto agar) supplemented with $1 \%$ of the corresponding sludge with the $\mathrm{pH}$ of media adjusted to 7.0, the most suitable $\mathrm{pH}$ to enhance and promote the growth of large number of bacteria. Plates were incubated at $37^{\circ} \mathrm{C}$ for $48 \mathrm{~h}$. Following incubation, colonies having macroscopically different morphologies were picked from each plate and re-streaked on LB agar media to obtain pure cultures. For long term storage, isolates were grown overnight in $10 \mathrm{ml} \mathrm{LB}$ medium $(\mathrm{pH}$ 7.0) under agitation at $230 \mathrm{rpm}$ and $1 \mathrm{ml}$ of each overnight culture stored as suspension in $30 \%(\mathrm{v} / \mathrm{v})$ glycerol at $-80{ }^{\circ} \mathrm{C}$.

\section{Morphological identification and physiological characterization of the different strains}

For each isolate the colony characteristics (shape, size, pigmentation, texture, and opacity), cell morphology, and Gram stain reaction were determined. Catalase and oxidase activities were determined as described by MeddebMouelhi et al. (2015).

\section{Screening of hydrolytic enzyme-producing bacteria}

Single colonies from fresh LB agar plates were patched onto minimal media $(\mathrm{Mm})$ agar plates $\left(0.1 \% \mathrm{NaNO}_{3}\right.$, $0.1 \% \mathrm{~K}_{2} \mathrm{HPO}_{4}, 0.05 \% \mathrm{MgSO}_{4}, 0.1 \% \mathrm{KCl}, 0.05 \%$ yeast extract and $1.5 \%$ Bacto agar) $\mathrm{pH} 7.0$, incubated at $37^{\circ} \mathrm{C}$, and supplemented with the appropriate substrate for extracellular hydrolytic enzyme detection (Charbonneau et al. 2011). For the detection of extracellular enzyme activity, buffered $\mathrm{Mm}$ was supplemented with the following substrates: glyceryl tributyrate $1 \%(\mathrm{v} / \mathrm{v})$ for esterase activity; olive oil $1 \%(\mathrm{v} / \mathrm{v})$ containing Rhodamine B $0.001 \%(\mathrm{w} / \mathrm{v})$ for detection of lipolytic activity (Fariha et al. 2010; Gupta et al. 2004; Jaeger and Reetz 1998); carboxymethyl cellulose (CMC) $0.5 \%(\mathrm{w} / \mathrm{v})$ for CMCase activity and Phosphoric Acid Swollen Avicel (PASA) $0.1 \%(\mathrm{w} / \mathrm{v})$ for PASAase activity (Kubicek et al. 2009; Singh and Prabhu 1986; Wang et al. 2010). Remazol Brillant Blue-xylan (RBB-xylan) from beechwood $0.5 \%(\mathrm{w} / \mathrm{v})$ was used for xylanase activity. Starch $1 \%(\mathrm{w} / \mathrm{v})$ was used for amylase activity (Meddeb-Mouelhi et al. 2015; Nigam and Singh 1995) and $1 \%$ of casein (w/v) was used for protease activity (Nigam and Pandey 2009; Nigam et al. 2013; Van Dyke 2004). Lipolytic activity was visualized by illuminating the plate with UV light (302 $\mathrm{nm}$ ) which results in an orange fluorescence detected at $535 \mathrm{~nm}$ around colony producing lipase (Patil et al. 2011; Sharyo 1993). Extracellular esterase activity was observed by appearance of a clear zone around the colonies (Kuhad et al. 1997; Meddeb-Mouelhi et al. 2015). CMCase and PASAase activities were detected by staining the plates using $0.2 \%$ Congo red for $15 \mathrm{~min}$ and then de-stained by washing twice with $1 \mathrm{M} \mathrm{NaCl}$ for 15 min (MeddebMouelhi et al. 2015). Xylanase positives clones were identified by a clear zone around the colonies on RBB-xylan plate (Meddeb-Mouelhi et al. 2015). Industrial enzymes (lipases, cellulases, xylanases and esterases purchased from Buckman North America) were used as positive controls.

\section{Detection of ligninolytic enzymes}

Laccase activity was detected using $\mathrm{Mm}$ agar plates at $\mathrm{pH}$ 5.0, supplemented with $6 \mathrm{mM}$ ABTS (3-ethylbenzothiazoline-6-sulphonic acid) and $100 \mathrm{mM}$ of $\mathrm{CuSO}_{4}$. After incubation at $37^{\circ} \mathrm{C}$, a positive reaction was indicated by the appearance of a green or violet color surrounding the bacterial colony (Arora and Sandhu 1985; D'Souza et al. 2009). LiP activity was screened for using $\mathrm{Mm}$ agar plates supplemented with $2 \mathrm{mM}$ hydrogen peroxide $\left(\mathrm{H}_{2} \mathrm{O}_{2}\right)$ (30\%) and $0.02 \%$ Azure B at $37^{\circ} \mathrm{C} \mathrm{pH} 7.0$ as described by Arora and Sandhu (1985). Isolates displaying LiP activity were detected by the appearance of clear halo around the colonies (Oyadomari et al. 2003; Singh and Prabhu 1986; Wongwilaiwalin et al. 2010). The detection of MnP activity was carried out as previously described by Orth et al. (1993) using Boyd and Kohlmeyer (B\&K) agar plates $(0.1 \%$ yeast extract, $0.2 \%$ peptone, $1 \%$ dextrose, $1 \mathrm{mM} \mathrm{CuSO}_{4}$, and $1.5 \%$ Bacto agar) supplemented with $0.1 \%$ magnesium sulfate and $0.1 \%$ phenol red $(\mathrm{w} / \mathrm{v})$, 
neutralized at $\mathrm{pH} 7.0$ and incubated at $37^{\circ} \mathrm{C}$. A positive reaction elicited by a yellow zone surrounding the colony (Hofrichter 2002; Oliveira et al. 2009; Orth et al. 1993).

\section{Bacteria growth and agar plate decolorization of Kraft pulping liquors}

In this experiment, three different Kraft pulping liquors (black, green and white), obtained from an Eastern Canadian paper mill were used. Colonies isolated from the same paper mill as described above were patched onto minimal media $(\mathrm{Mm})$ agar plates $\left(0.1 \% \mathrm{NaNO}_{3}\right.$, $0.1 \% \mathrm{~K}_{2} \mathrm{HPO}_{4}, 0.05 \% \mathrm{MgSO}_{4}, 0.1 \% \mathrm{KCl}, 0.05 \%$ yeast extract and $1.5 \%$ Bacto agar) supplemented with $5 \%$ of each liquor (Negrão et al. 2015). All the tests were done at $\mathrm{pH} 12.0$, the closest to real $\mathrm{pH}$ of pulping liquors, and incubated at $37{ }^{\circ} \mathrm{C}$. Both the rate of colony growth and features (appearance and color) were recorded over the 5 days of incubation.

\section{Bacteria decolorization of lignin-mimicking dyes}

Four different lignin-mimicking dyes, methyl blue (MB), methyl green (MG), remazol brilliant blue (RBB) and Chicago sky blue (CSB) were used in this study. Dye decolorization by the isolates was carried out according to Kiiskinen et al. (2004). Bacteria were picked onto $\mathrm{Mm}$ or LB agar plates ( $\mathrm{pH} 7.0)$ supplemented with $0,05 \%(\mathrm{w} / \mathrm{v})$ of the dye. The respective dye activity was visualized within $24-48 \mathrm{~h}$ of incubation at $37^{\circ} \mathrm{C}$. The appearance of a decolorized halo surrounding the colony indicated the dye degradation by the bacteria. The color of cell colony was also visually inspected to establish whether the dye had been absorbed by the colony rather than being degraded (Daizong et al. 2014; Wesenberg et al. 2003).

\section{Identification of PHA producing bacteria}

PHA-producing bacteria were identified with two different staining methods using Sudan Black B (SBB) and Nile Blue A (NBA). For the first method, bacteria were grown on PHA Detection (PD) liquid medium $(0.2 \%$ $\left(\mathrm{NH}_{4}\right)_{2} \mathrm{SO}_{4}, 1.33 \% \mathrm{KH}_{2} \mathrm{PO}_{4}, 0.13 \% \mathrm{MgSO}_{4}, 0.17 \%$ citric acid, $2 \%$ of glucose as carbon source and $10 \mathrm{~mL} / \mathrm{L}$ of trace element solution) as described by Naheed and Jamil (2014). Media culture pH was adjusted to 7.0. After overnight incubation, $200 \mu \mathrm{l}$ bacteria culture were re-streaked on PHA Detection Agar (PDA) as described in Gomaa (2014). After $24 \mathrm{~h}$ incubation at $37^{\circ} \mathrm{C}$, PHA accumulation in cells was detected by SBB staining method. For this, $0.002 \%$ SBB solution in $100 \%$ ethanol was gently spread over the plates completely soaking them, and then the plate incubated at room temperature for 30-60 $\mathrm{min}$ (Rieger et al. 2002). The solution was then discarded and the plate rinsed gently with $100 \%$ ethanol. Colonies unable to incorporate SBB appeared white, while
PHA producers appeared bluish black. All isolated which appeared to produce PHA were confirmed by NBA (Nile Blue A) staining according to Kitamura and Doi (1994).

\section{PCR amplification of 16S rRNA gene and sequencing} Genomic DNA was isolated from selected organisms by 2 heat shock cycles $\left(15 \mathrm{~min}\right.$ at $-80{ }^{\circ} \mathrm{C}$ and $10 \mathrm{~min}$ at $100{ }^{\circ} \mathrm{C}$ ). Amplification of $16 \mathrm{~S}$ rRNA gene was performed using the universal primers $1522 \mathrm{R}$ (sequence $5^{\prime}-3^{\prime}$ : AAGGAGGTGATCCANCCGCA), and 27F (sequence 5'-3': AGAGTTTGATCMTGGCTCAG). The PCR products were separated on a $0.8 \%$ agarose low melting gel and the band corresponding to $1.5 \mathrm{~kb} 16 \mathrm{~S}$ rRNA gene was purified using Qiagen MinElute PCR purification kit and then quantified. Purified PCR products were sequenced on both stands with an ABI Prism 3100 automatic sequencer at the Biomolecular analysis platform (University Laval, QC). Analysis of $16 \mathrm{~S}$ rDNA sequences were performed using Clone Manager professional 7.0 (Sci Ed Centra). The resulting sequences searched against the nucleotide collection at Genbank database using BLAST with the BLAST algorithm using the non-redundant nucleotide database GenBank via the National Center for Biotechnology Information (NCBI) website (Kumar et al. 2002; Meddeb-Mouelhi et al. 2015).

\section{Results and discussion}

\section{Identification of bacterial strains from paper mill sludge} samples

Forty-one strains were tentatively identified based on their 16S rRNA gene sequences (Table 2). The majority were closely related to previously identified species (97-99 \% DNA sequence similarity) and are identified as such. Others were more distantly related (86-95 \% DNA sequence similarity). The latter strains could represent new strains, different from the closest relatives listed in Table 2. Overall the strains aligned primarily within the phyla Firmicutes (61 \%) and Proteobacteria (39\%), and encompassed eleven different genera. Bacillus and Paenibacillus species accounted for twenty-five of the total strains, with the remainder related to species in the genera Aeromonas, Xanthomonas, Pseudoxanthomonas, Serratia, Rahnella, Pantoea, Citobacter, Klebsiella and Raoultella (Table 2). One possible limitation of this work is that both the isolation media and approach utilized may have affected the final distribution of strains across these samples. Specifically, there remains the possibility of additional anaerobic and uncultivable bacterial strains associated with these samples.

Species within the genera Bacillus, Paenibacillus and Xanthomonas have been found in paper mills in the USA, Finland, New Zealand and Canada to name a few (Beauchamp et al. 2006; Chiellini et al. 2014; Desjardins 
Table 2 Genetic identification of screened strains from paper mill sludges

\begin{tabular}{|c|c|c|c|}
\hline Strains & Phyllum & Genetic identification (closest relative) & $\%$ sequence identity \\
\hline PS1 & Firmicutes & Bacillus amylolequifaciens & 92 \\
\hline PS2 & Proteobacteria & Aeromonas salmonicida & 99 \\
\hline PS3 & Firmicutes & Paenibacillus sp. & 92 \\
\hline PS4 & Firmicutes & Paenibacilus sp. & 92 \\
\hline PS4.2 & Proteobacteria & Klebsiella pneumonia & 89 \\
\hline PS5 & Firmicutes & Bacillus subtilis & 94 \\
\hline PS6 & Firmicutes & Bacillus subtilis & 93 \\
\hline PS7 & Firmicutes & Bacillus sp. & 89 \\
\hline PS8 & Firmicutes & Bacillus subtilis & 86 \\
\hline PS9 & Firmicutes & Bacillus subtilis & 89 \\
\hline PS10 & Firmicutes & Bacillus subtilis & 99 \\
\hline PS11 & Firmicutes & Bacillus subtilis & 99 \\
\hline PS12 & Firmicutes & Paenibacillus sp. & 99 \\
\hline PS13 & Firmicutes & Bacillus tequilensis & 89 \\
\hline PS14 & Firmicutes & Bacillus sp. & 92 \\
\hline PS15 & Firmicutes & Bacillus thuringiensis & 98 \\
\hline PS16 & Proteobacteria & Citrobacter sp. & 98 \\
\hline PS17 & Firmicutes & Bacillus sp. & 98 \\
\hline PS18 & Firmicutes & Bacillus subtilis & 98 \\
\hline PS19 & Firmicutes & Bacillus cereus & 98 \\
\hline PS20 & Firmicutes & Bacillus thuringiensis & 98 \\
\hline PS21 & Firmicutes & Bacillus subtilis & 89 \\
\hline PS22 & Firmicutes & Bacillus subtilis & 86 \\
\hline MS1 & Proteobacteria & Klebsiella sp. & 97 \\
\hline MS2 & Proteobacteria & Xanthomonas sp. & 99 \\
\hline MS3 & Proteobacteria & Pantoea sp. & 98 \\
\hline MS4 & Firmicutes & Paenibacillus taichungensis & 95 \\
\hline MS5 & Proteobacteria & Serratia sp. & 98 \\
\hline MS6 & Proteobacteria & Serratia sp. & 98 \\
\hline MS7 & Proteobacteria & Pseudoxanthomonas taiwanensis & 98 \\
\hline MS8 & Proteobacteria & Raoultella terrigena & 98 \\
\hline MS9 & Proteobacteria & Raoultella terrigena & 98 \\
\hline MS10 & Proteobacteria & Serratia sp. & 98 \\
\hline MS11 & Firmicutes & Bacillus subtilis & 98 \\
\hline IS1 & Proteobacteria & Rahnella aquatilis & 98 \\
\hline IS2 & Proteobacteria & Rahnella sp. & 95 \\
\hline IS3 & Firmicutes & Bacillus sp. & 98 \\
\hline IS4 & Firmicutes & Bacillus cereus & 98 \\
\hline IIS1 & Proteobacteria & Aeromonas sp. & 97 \\
\hline IIS2 & Firmicutes & Paenibacillus sp. & 98 \\
\hline IIS3 & Proteobacteria & Aeromonas sp. & 98 \\
\hline
\end{tabular}

Phyllum and genetic identification of bacteria are conventionally written in italics

and Beaulieu 2003; Harju-Jeanty and Vaatanen 1984; Kämpfer et al. 2012; Schallmey et al. 2004; Martin 1988; Niemelä and Väätänen 1982). We found that the dominant genus in our mill was Bacillus, confirming previous biodiversity studies in pulp and slime samples from different Canadian paper mills (Desjardins and Beaulieu 2003; Maki et al. 2011). We also isolated species in the genera Paenibacillus, Raoultella, Serratia, Klebsiella and Xanthomonas which have not previously been reported in earlier paper mill biodiversity studies. Differences 
in microflora also occurred among the sludge samples. Twenty-three strains originated from PS sludge, eleven from MS, and much fewer from the IS and IIS samples (4 and 3 strains respectively).

\section{Morphological and physiological characterization of strains from paper mill sludge samples}

Strains were further characterized on the basis of colony morphology (colour, shape, margin, elevation and texture), cell morphology, Gram reaction, oxidase, and catalase activities (Additional file 1: Table S1). Twentyone strains displayed oxidase and catalase activities, sixteen showed only catalase, and four strains only oxidase activity. Thirty-one strains were bacilli (rod-shaped) and stained Gram-positive. Ten strains were cocci and stained Gram-negative (see Additional file 1: Table S1). The majority of bacteria isolated from IS and PS were Gram-positive, whereas the majority of MS and IIS were Gram-negative.

All strains were tested for their ability to grow at various $\mathrm{pH}$ and temperatures. Among the strains, twentyone grew at $\mathrm{pH}$ ranging from 6 to 10, while twelve strains grew at $\mathrm{pH}$ ranging from 7 to 10 . The remaining eight strains grew only at neutral $\mathrm{pH}$ (Additional file 1: Table S2). Strains were also tested for their ability to grow at $50{ }^{\circ} \mathrm{C}$. All of the strains isolated from PS grew at $50{ }^{\circ} \mathrm{C}$ at $\mathrm{pH}$ values up to 10 , with the exception of strains PS5, PS7, PS12, PS15 and PS17 which grew only at neutral pH (Additional file 1: Table S2). Strains isolated from other environmental samples MS, IS and IIS were generally unable to grow at $50^{\circ} \mathrm{C}$, with the exception of two strains (MS1 and MS2).

While various Bacillus spp. were isolated from all of the sludge samples, they dominated the cultivable community from PS. The finding is not unexpected, as species within this genus have been detected in a wide range of environmental screening studies (Desjardins and Beaulieu 2003; Vaisanen et al. 1991). Furthermore, sludge samples contain a rich content of polymers (cellulose and hemicellulose), and PS being a combinational end-product is more concentrated than the IS and IIS sludge used to produce it and accordingly, revealed to be the most prolific medium regarding biodiversity.

\section{Hydrolytic activities associated with the bacteria screened from paper mill sludge}

All strains were screened for seven different hydrolytic activities (CMCase, PASAase, xylanase, esterase, lipase, protease and amylase) (Table 3). Overall, twenty-one strains expressed extracellular cellulase (CMCase and/ or PASAase). Among these, fourteen showed a preference for $\mathrm{CMC}$, whereas four others preferred amorphous cellulose-rich PASA, and three strains PS1, PS5, and PS10 hydrolysed both CMC and PASA. The remaining twenty strains were xylanase positive and were primarily related to species in the genus Bacillus. Only four strains displayed both cellulase and xylanase activity. These were IIS1, IS3, PS21 and MS10, and were identified as Aeromonas sp., Bacillus sp., Bacillus subtilis and Serratia sp. respectively.

Bacteria isolated from PS demonstrated either cellulose or xylanase activity, whereas those from MS strains were predominantly xylanolytic, with a few showing cellulase activity. Strains isolated from IS and IIS were better producers of cellulase than xylanase. Higher numbers of xylanase producers from MS likely reflect the abundance of xylan fibers in this particular environmental sample (Raj et al. 2013). All strains isolated from PS displayed extracellular esterase activity when grown on tributyrate agar plate except for strains PS15 and PS17. Nine strains (PS3, PS7, PS8, PS11, PS12, PS13, PS14, PS20 and PS22) identified as various Bacillus and Paenibacillus strains displayed both lipolytic activities (esterase and lipase). Fourteen strains isolated from PS showed no secreted lipase activity. Four strains isolated from samples taken from machinery (MS1, MS2, MS9 and MS10), three from IIS (IIS1, IIS2 and IIS3) and one from IS (IS1) were also esterase positive. No lipase activity was found in the strains isolated from MS, IS and IIS samples as shown in Table 3. The secretion of esterase observed here appears to be a consequence of PS particular composition, which includes wax esters. Most IIS and PS strains showed esterase activities, unlike those from MS and IS. Lack of lipolytic activities in MS sludge can be explained by its low content in extractible lipidous material.

Screening using agar plates supplemented with starch and casein revealed that 9 strains from PS (PS2, PS5, PS6, PS9, PS13, PS14, PS18, PS20 and PS22), one from MS (MS3) and one from IS (IS3) displayed both amylase and protease activities (Table 3). These strains were predominantly related to Bacillus. Twenty strains from various genera (Bacillus, Paenibacillus, Aeromonas, Xanthomonas, Serratia, Rahnella, Pantoea, Klebsiella and Raoultella) were amylase and protease negative. We also found that only three strains (MS7, IIS1 and PS16) were amylase positive, and seven (PS1, PS4.2, PS10, PS11, MS5, MS9 and MS11) were protease positive. The finding that most strains produced esterase activity (twenty-nine), cellulase (twenty-two) and xylanase (twenty-three) was no real surprise. In fact, the majority of available substrate in this Kraft paper mill are triglycerides, wax esters, cellulose and hemicelluloses fibers (xylan) (Pervaiz and Sai 2012).

Isolates in the genus Bacillus are known for their diversity of enzymatic activities. The capacity of certain 
Table 3 Enzymatic activities of screened bacterial strains on agar plate with relevant substrate at $37^{\circ} \mathrm{C}$ and $\mathrm{pH} 7$

\begin{tabular}{|c|c|c|c|c|c|c|c|c|c|c|c|}
\hline \multirow[t]{2}{*}{ Strains } & \multirow[t]{2}{*}{ Genetic identification } & \multicolumn{7}{|c|}{ Hydrolytic enzymes } & \multicolumn{3}{|c|}{ Ligninolytic enzymes } \\
\hline & & Est & Lip & CMC & PASA & Xyl & Amyl & Prot & LiP & $\mathrm{MnP}$ & $\operatorname{Lac}^{*}$ \\
\hline PS1 & Bacillus amylolequifaciens & + & - & + & + & - & - & + & - & + & + \\
\hline PS2 & Aeromonas salmonicida & + & - & + & - & - & + & + & - & - & - \\
\hline PS3 & Paenibacillus sp. & + & + & + & - & - & - & - & + & - & + \\
\hline PS4 & Paenibacilus sp. & + & - & + & - & - & - & - & - & - & - \\
\hline PS4.2 & Klebsiella pneumonia & + & - & + & - & - & - & + & + & + & + \\
\hline PS5 & Bacillus subtilis & + & - & + & + & - & + & + & + & - & - \\
\hline PS6 & Bacillus subtilis & + & - & + & - & - & + & + & - & + & - \\
\hline PS7 & Bacillus sp. & + & + & + & - & - & - & - & - & - & - \\
\hline PS8 & Bacillus subtilis & + & + & + & - & - & - & - & + & - & - \\
\hline PS9 & Bacillus subtilis & + & - & + & - & - & + & + & - & - & - \\
\hline PS10 & Bacillus subtilis & + & - & + & + & - & - & + & + & - & - \\
\hline PS11 & Bacillus subtilis & + & + & + & - & - & - & + & + & - & - \\
\hline PS12 & Paenibacillus sp. & + & + & + & - & - & - & - & + & + & + \\
\hline PS13 & Bacillus tequilensis & + & + & + & - & - & + & + & - & - & - \\
\hline PS14 & Bacillus sp. & + & + & - & - & + & + & + & - & + & - \\
\hline PS15 & Bacillus thuringiensis & - & - & - & - & + & - & - & - & - & - \\
\hline PS16 & Citrobacter sp. & + & - & - & - & + & + & - & - & - & - \\
\hline PS17 & Bacillus sp. & - & - & - & - & + & - & - & - & - & - \\
\hline PS18 & Bacillus subtilis & + & - & - & - & + & + & + & + & - & + \\
\hline PS19 & Pantoea sp. & + & - & - & - & + & - & - & - & - & - \\
\hline PS20 & Bacillus thuringiensis & + & + & - & - & + & + & + & + & - & + \\
\hline PS21 & Bacillus subtilis & + & - & - & + & + & - & - & + & - & - \\
\hline PS22 & Bacillus subtilis & + & + & - & - & + & + & + & - & + & + \\
\hline MS1 & Klebsiella sp. & + & - & + & & & & & + & & + \\
\hline MS2 & Xanthomonas sp. & + & - & + & - & - & - & - & - & - & - \\
\hline MS3 & Bacillus cereus & - & - & - & - & + & + & + & + & + & - \\
\hline MS4 & Paenibacillus taichungensis & - & - & - & - & + & - & - & + & + & - \\
\hline MS5 & Serratia sp. & - & - & - & - & + & - & + & - & + & - \\
\hline MS6 & Serratia sp. & - & - & - & - & + & - & - & - & - & + \\
\hline MS7 & Pseudoxanthomonas taiwanensis & - & - & - & - & + & + & - & - & - & - \\
\hline MS8 & Raoultella terrigena & - & - & - & - & + & - & - & - & - & - \\
\hline MS9 & Raoultella terrigena & + & - & - & - & + & - & + & + & + & + \\
\hline MS10 & Serratia sp. & + & - & - & + & + & - & - & - & - & - \\
\hline MS11 & Bacillus subtilis & - & - & - & - & + & - & +- & - & - & - \\
\hline IS1 & Rahnella aquatilis & + & - & + & - & - & - & - & - & - & - \\
\hline 152 & Rahnella sp. & - & - & + & - & - & - & - & + & - & + \\
\hline 153 & Bacillus sp. & - & - & - & + & + & + & + & - & - & + \\
\hline IS4 & Bacillus cereus & - & - & - & - & + & - & - & - & - & - \\
\hline ॥S1 & Aeromonas sp. & + & - & - & + & + & + & - & - & - & - \\
\hline IIS2 & Paenibacillus sp. & + & - & - & - & + & - & - & - & - & - \\
\hline IIS3 & Aeromonas sp. & + & - & - & - & + & - & - & - & - & - \\
\hline
\end{tabular}

Est esterase, Lip lipase, CMC CMCase, PASA PASAase, Xyl xylanase, Amyl amylase, LiP lignin peroxidases, MnP manganese peroxidase, Lac laccase, Prot protease

* Test done at $\mathrm{pH} 5$ for 7 days incubation

Bacillus strains to both produce and secrete a large array of extracellular enzymes made them among the most important industrial bacteria producing for enzymes [contributing to about $50 \%$ of the total enzyme market
(Adrio and Demain 2005; Fisher et al. 2014; Houde et al. 2004)]. ${ }^{1}$ In regard to all of the hydrolytic activities

\footnotetext{
${ }^{1}$ http://www.prnewswire.com/news-releases/global-markets-for-enzymesin-industrial-applications-266011071.html.
} 
(hydrolase, glycosidase and protease), five strains isolated from PS displayed five of the seven hydrolytic activities which we tested for. These strains included Bacillus subtilis PS5, Bacillus tequilensis PS13, Bacillus sp. PS14, Bacillus thuringiensis PS20 and Bacillus subtilis PS22 (Table 3). Overall, the variability in strain enzymatic profiles likely reflects differences in sludge composition or conditions, and adaptation of the microflora to each specific environment. Again, both the detection methods and substrates used for detection of enzymatic activities can impact the observed enzymatic profiles. For instance in the case of enzymes that are not secreted, they would not likely be detected. Moreover, the limited number of substrates used here will not reveal all of the potential enzymatic activities present in any given sample.

\section{Detection of ligninolytic enzymes}

To further characterize biodiversity we examined the ligninolytic potential of these strains. Ligninolytic enzymatic activities screened for including laccase (Lac), lignin peroxidase ( $\mathrm{LiP}$ ) and manganese peroxidase $(\mathrm{MnP})$ (Hofrichter 2002; Kumar et al. 2008; Martínez et al. 2005). Twenty-two strains expressed at least one extracellular ligninolytic enzymatic activity (Table 3 ). Three strains (Paenibacillus sp. PS12, Klebsiella pneumonia PS4.2 and Raoultella terrigena MS9) produced all three activities, whereas nineteen strains showed none.

Strains isolated from PS sludge demonstrated the greatest number of extracellular ligninolytic activities compared to MS, IS and IIS where these activities were not detected. This may be due to both compositional and environmental differences among these sludges. In fact, the former contains organic matter such as cellulose, lignin and wood extracts (Negrão et al. 2015; Oyadomari et al. 2003) which make this sludge an optimal niche for ligninolytic enzymes producing bacteria. Paenibacillus strains have previously been identified in paper mill samples; however unlike strains PS12, PS4, and IIS2, no enzymatic activity profiles were reported before (Kämpfer et al. 2012; Oliveira et al. 2009; Woo et al. 2014). Xanthomonas and Pseudoxanthomonas showed none of the three ligninolytic enzymatic activities (Lip, Lac and $\mathrm{MnP})$. Interestingly as found with various hydrolytic activities, the Bacillus strains demonstrated a wide and variable range for this trait (Table 3).

\section{Decolorization and utilisation of pulping liquors as carbon source by bacteria}

Strains were screened for their potential for bioremediation of black, green and white pulping liquors (Table 4). Growth was tested using Mm agar plates supplemented with pulp liquors as the sole carbon source $(5 \% \mathrm{v} / \mathrm{v})$ at both $\mathrm{pH} 7.0$ (data not shown) and $\mathrm{pH}$ 12.0, and temperature of $37{ }^{\circ} \mathrm{C}$ as previously described (Negrão et al. 2015). Thirty-two strains grew at $\mathrm{pH} 12.0$ within $48 \mathrm{~h}$ on $\mathrm{Mm}$ medium containing pulping liquor(s) as sole carbon source (Chandra et al. 2011; Daizong et al. 2014; Wesenberg et al. 2003).

Twenty-four strains grew and decolorized medium containing black liquor. Black liquor contains a high content of lignin (>40 \%) (Huang et al. 2007; Schallmey et al. 2004; Negrão et al. 2015), in addition to organic acids, and various polysaccharide degradation by-products (Martínez et al. 2005; Mathews et al. 2013). Among this group, fifteen strains in the genera Pantoea, Paenibacillus, Bacillus, Citrobacter, Klebsiella, Pneumonia and Aeromonas demonstrated the ability to adsorb the black color from the agar medium within $24 \mathrm{~h}$, and eventually decolorize the compounds responsible for its dark colour (Table 4). This absorption/degradation phenomenon is similar to that reported by Bandounas et al. (2011). These strains were predominantly isolated from IS, PS and MS sludge.

Twenty-two strains grew on Mm medium supplemented with $5 \%$ green liquor ( $\mathrm{pH} 12.0$ ) within $24 \mathrm{~h}$ (Table 4). This liquor is a poor source for lignin (Van Dyke 2004). Certain strains (Paenibacillus PS12, Raoultella MS9 and Serratia MS10) grew on the green liquor but not on black or white liquors, suggesting that these strains are either adapted to a lower lignin content than the one found in black liquor or are inhibited by other compounds present in the black liquor.

White liquor is the poorest source of carbon among the three liquors, consisting primarily of inorganics $\left(\mathrm{Na}_{2} \mathrm{~S}\right.$, $\mathrm{NaOH}$ and $\left.\mathrm{Na}_{2} \mathrm{CO}_{3}\right)$. Only thirteen strains belonging to Paenibacillus strains PS3 and PS4, Klebsiella strains PS4.2, PS5, PS6, PS8, PS13 and PS18, Bacillus IS3, Xanthomonas MS2, Pantoea MS3, Serratia MS6 and Pseudoxanthomonas MS7 were able to grow on Mm agar plate supplemented with $5 \%$ white liquor at $\mathrm{pH} 12.0$ (Table 4). Certain strains (MS6, MS7, PS3 and PS5) which were unable to grow and stand high lignin concentrations found in black liquor were able to grow on the other liquors, while nine strains (PS15, PS17, PS20, PS22, IS1, IS4) and all IIS strains were unable to grow on any of the three liquors.

Five strains Paenibacillus PS4 and PS6, Bacillus subtilis PS8, Bacillus tequilensis PS13 and Bacillus cereus MS3 were able to grow on all the three liquors, suggesting a high degree of resistance to the compounds present in this material (phenolic compounds, organic and inorganic content) as well as the ability to metabolise components contained within. Bacteria isolated from IIS showed no growth on pulping liquor, while strains originating in IS showed a preference for black liquor whereas 
Table 4 Detection of metabolic pathways with potential industrial applications

\begin{tabular}{|c|c|c|c|c|c|c|c|c|c|}
\hline \multirow[t]{2}{*}{ Strains } & \multicolumn{4}{|c|}{ Dyes decolorization (pH7) } & \multicolumn{3}{|c|}{$\mathrm{Mm}+5 \%$ liquors ( $\mathrm{pH} 12)$} & \multicolumn{2}{|c|}{ PHA synthesis (pH7) } \\
\hline & MB & RBB & MG & CSB & Black & Green & White & Sudan black & Nile blue \\
\hline PS1 & D & $\mathrm{D}$ & $+^{a}$ & W & $+^{\mathrm{a}}$ & + & - & $\mathrm{p}^{+}$ & $\mathrm{p}^{+}$ \\
\hline PS2 & $t^{\mathrm{a}}$ & - & - & $+^{\mathrm{a}}$ & $t^{\mathrm{a}}$ & + & - & - & - \\
\hline PS3 & D & - & - & $\mathrm{D}$ & - & + & + & w & $\mathrm{P}^{-}$ \\
\hline PS4 & D & $+^{\mathrm{a}}$ & - & $+^{\mathrm{a}}$ & $+^{a}$ & + & + & $\mathrm{P}^{+}$ & $\mathrm{P}^{+}$ \\
\hline PS4.2 & D & $\mathrm{D}$ & $+^{\mathrm{a}}$ & + & $t^{\mathrm{a}}$ & - & + & $w^{-}$ & $\mathrm{P}^{+}$ \\
\hline PS5 & $\mathrm{D}$ & - & $\mathrm{D}$ & $+^{\mathrm{a}}$ & - & + & + & $\mathrm{P}^{+}$ & $\mathrm{P}^{-}$ \\
\hline PS6 & $++^{a, e}$ & $+^{\mathrm{a}, \mathrm{e}}$ & - & $+^{\mathrm{a}}$ & + & + & + & - & - \\
\hline PS7 & $D$ & $+^{\mathrm{a}, \mathrm{e}}$ & $+^{a}$ & $+^{a}$ & + & + & - & $\mathrm{p}^{+}$ & $\mathrm{p}^{+}$ \\
\hline PS8 & $D$ & $+^{\mathrm{a}}$ & - & - & $+^{\mathrm{a}}$ & + & + & $\mathrm{P}^{+}$ & $\mathrm{P}^{+}$ \\
\hline PS9 & $t^{a}$ & - & - & $+^{\mathrm{a}}$ & $+^{\mathrm{a}}$ & - & - & $\mathrm{P}^{+}$ & $\mathrm{P}^{+}$ \\
\hline PS10 & $D$ & - & - & $+^{\mathrm{a}}$ & + & - & - & $\mathrm{P}^{+}$ & $\mathrm{P}^{+}$ \\
\hline PS11 & $D$ & - & - & $+^{\mathrm{a}}$ & $+^{a}$ & + & - & $\mathrm{P}^{+}$ & $\mathrm{P}^{+}$ \\
\hline PS12 & $D$ & D & - & $+^{a}$ & - & + & - & $\mathrm{P}^{+}$ & $P^{-}$ \\
\hline PS13 & $+^{a}$ & - & - & $+^{\mathrm{a}}$ & + & + & + & $\mathrm{P}^{+}$ & $\mathrm{P}^{+}$ \\
\hline PS14 & $D$ & $t^{a}$ & - & - & + & + & - & $\mathrm{P}^{+}$ & $\mathrm{P}^{+}$ \\
\hline PS15 & $t^{a}$ & - & - & $+^{\mathrm{a}}$ & - & - & - & $\mathrm{P}^{+}$ & $\mathrm{P}^{+}$ \\
\hline PS16 & $t^{a}$ & $D$ & - & $+^{\mathrm{a}}$ & $+^{\mathrm{a}}$ & +- & - & $\mathrm{P}^{+}$ & $\mathrm{P}^{+}$ \\
\hline PS17 & $t^{a}$ & - & - & $\mathrm{D}$ & - & - & - & - & - \\
\hline PS18 & $D$ & - & - & - & + & - & + & $\mathrm{P}^{+}$ & $\mathrm{P}^{+}$ \\
\hline PS19 & $t^{a}$ & - & - & - & $+^{a}$ & - & - & $\mathrm{P}^{+}$ & $\mathrm{P}^{-}$ \\
\hline PS20 & $D$ & $D$ & - & D & - & - & - & $\mathrm{p}^{+}$ & $\mathrm{p}^{+}$ \\
\hline PS21 & $D$ & - & $+^{a}$ & $+^{a}$ & $+^{a}$ & + & - & w & $\mathrm{P}^{-}$ \\
\hline PS22 & $D$ & $D$ & - & - & - & - & - & w & w \\
\hline MS1 & $D$ & W & $+^{a}$ & D & + & - & - & $\mathrm{P}^{+}$ & $\mathrm{P}^{+}$ \\
\hline MS2 & $D$ & $D$ & - & - & - & - & + & - & - \\
\hline MS3 & $D$ & $+^{\mathrm{a}}$ & + & $D$ & $+^{\mathrm{a}}$ & + & + & $\mathrm{P}^{-}$ & $\mathrm{P}^{-}$ \\
\hline MS4 & $D$ & $D$ & $+^{a}$ & - & + & + & - & - & - \\
\hline MS5 & - & + & - & $D$ & + & - & - & $\mathrm{P}^{+}$ & $\mathrm{P}^{+}$ \\
\hline MS6 & $D$ & $+^{\mathrm{a}, \mathrm{e}}$ & $W^{a}$ & $+^{\mathrm{a}}$ & - & + & + & - & - \\
\hline MS7 & $+^{a}$ & $+^{\mathrm{a}}$ & $+^{\mathrm{a}, \mathrm{e}}$ & $+^{a}$ & - & + & + & $\mathrm{p}^{+}$ & $\mathrm{p}^{+}$ \\
\hline MS8 & $t^{a}$ & $+^{\mathrm{a}}$ & - & $D$ & $+^{\mathrm{a}}$ & + & - & - & - \\
\hline MS9 & $D$ & - & - & $D$ & - & + & - & $\mathrm{P}^{+}$ & $\mathrm{P}^{+}$ \\
\hline MS10 & $w^{a}$ & $+^{\mathrm{a}}$ & $D$ & $D$ & - & + & - & - & - \\
\hline MS11 & $w^{a}$ & $++^{\mathrm{a}}$ & $D$ & $D$ & $+^{a}$ & + & - & $\mathrm{P}^{+}$ & $\mathrm{P}^{+}$ \\
\hline IS1 & $t^{a}$ & - & - & D & - & - & - & $\mathrm{p}^{+}$ & $\mathrm{p}^{+}$ \\
\hline IS2 & $D$ & - & $W^{a}$ & $+^{\mathrm{a}, \mathrm{e}}$ & $+^{a}$ & - & - & - & - \\
\hline IS3 & $D$ & - & - & + & $+^{a}$ & - & + & $\mathrm{P}^{+}$ & $\mathrm{P}^{+}$ \\
\hline IS4 & $t^{a}$ & - & - & $+^{\mathrm{a}}$ & - & - & - & w & $w^{-}$ \\
\hline IIS1 & $+^{a}$ & $D$ & - & $+^{a}$ & - & - & - & $\mathrm{P}^{+}$ & $\mathrm{p}^{+}$ \\
\hline IIS2 & $D$ & $+^{\mathrm{a}}$ & $D$ & $D$ & - & - & - & $\mathrm{P}^{+}$ & $\mathrm{P}^{+}$ \\
\hline IIS3 & $+^{a}$ & $+^{\mathrm{a}, \mathrm{e}}$ & - & $D$ & - & - & - & - & - \\
\hline
\end{tabular}

Superscript letter a: absorption; e: elimination

+ , growth; -, no growth; $\mathrm{w}$, weak growth; $\mathrm{P}^{+}$, PHA positive; $\mathrm{P}^{-}$, PHA negative; $\mathrm{w}$, weak production of PHA; $\mathrm{D}$, dyes degradation; RBB, Remazol Brilliant Blue; MG, Methyl Green; MB, Methyl Blue; CSB, Chicago Sky Blue 
those from MS preferred green liquor. Finally, strains isolated from PS showed preference to black liquor and grew on green but had little affinity toward white pulping liquor. Clearly, a consortium of selected sludge bacterial strains might become the spearhead of an efficient lignin degradation strategy. In addition, they may also find application for decreasing color associated with black liquor, enhancing a number of paper mills' products.

\section{Decolorization of industrial dyes by sludge bacteria}

In order to address the use of these strain for potential use in bioremediation of industrial dyes we screened them on solid medium containing four different ligninolytic indicator dyes or synthetic lignin-mimicking dyes $(0.05 \% \mathrm{w} / \mathrm{v})$ : Methyl blue (MB), Chicago sky blue (CSB), Methyl green (MG) and Remazol brillant blue (RBB; see
Fig. 1). Ten strains decolourized all four dyes (Table 4). Among these Paenibacillus and Bacillus strains were the most efficient, decolourizing the dyes after only $24 \mathrm{~h}$ incubation (Table 4), in common with recently described abilities in related strains. The ability to degrade these dyes was not limited to specific genera, and various strains of Bacillus, Paenibacillus, and Klebsiella had this capability. Methyl blue (MB) and Chicago sky blue (CSB) are the most similar to lignin, and were decolorized by the most of the strains examined (Table 4). Much fewer strains were able to decolorize RBB and MG dye (twentytwo and fourteen strains respectively; Table 4). Furthermore, there was no strict correlation between the ability to decolorize industrial dyes and to grow on pulping liquors, suggesting that different pathways control these characteristics.
1. Methyl Blue

(MB)

2. Remazol Brillant Blue

(RBB)

3. Methyl Green

(MG)

4. Chicago Sky Blue

(CSB) a Before incubation
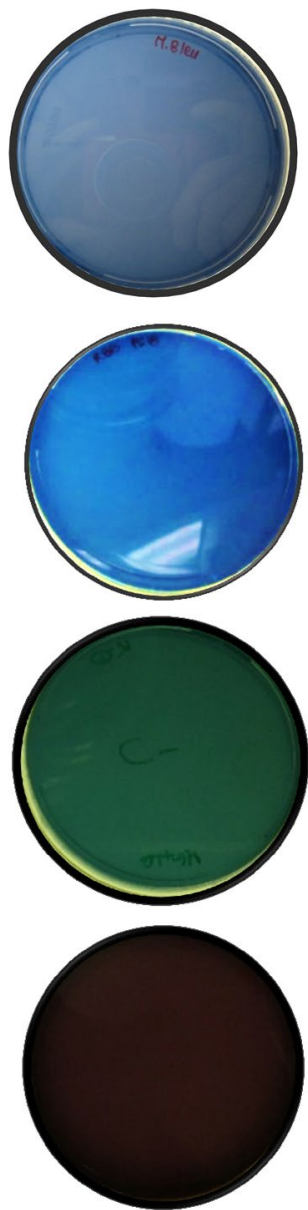

b After incubation
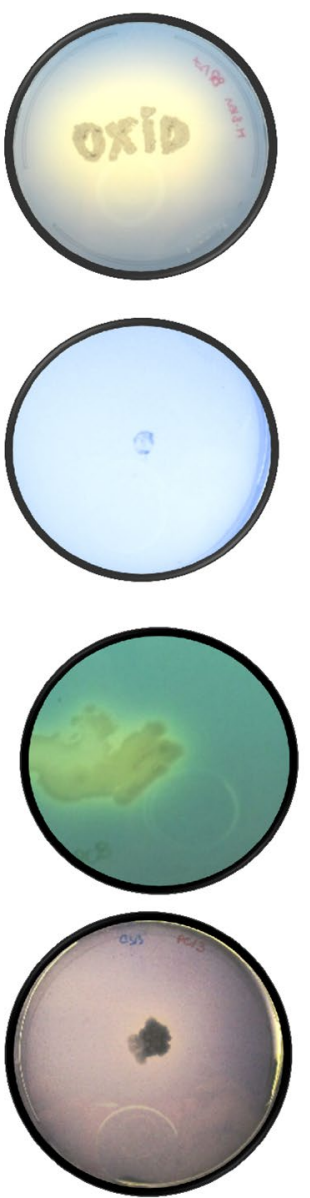

c negative control
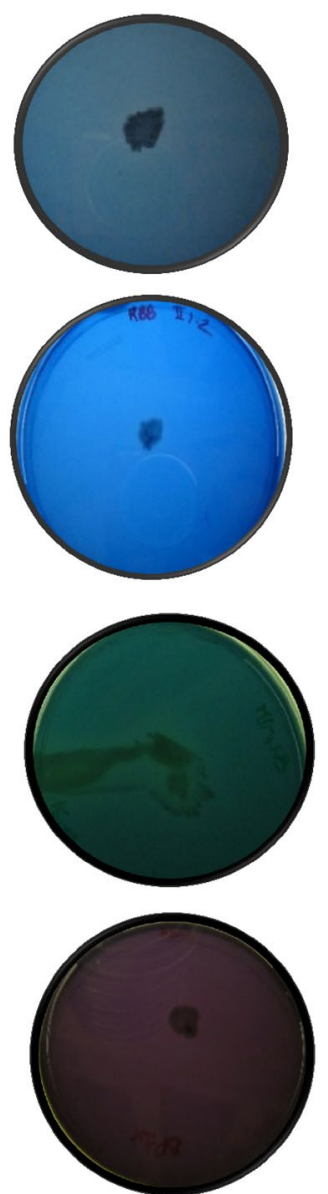

Fig. 1 Examples of isolated bacterial decolorization of dye-containing plates. Decolorization of 0.05 \% dye-containing plates (1.MB, 2.RBB, 3.MG and 4.CSB) after $24 \mathrm{~h}$ incubation at $37^{\circ} \mathrm{C}$ and $\mathrm{pH} 7$ 
In fungi, decolorization of dye proceeds via three different mechanisms, as recently described by Blanca et al. (2007). These include (1) absorption and concentration of the dye (2) intracellular absorption and subsequent degradation of the dye and (3) extracellular degradation of dye. We observed similar mechanisms to decolourize these dyes with our strains (Fig. 2).

This previous study showed that the dyes [they used dyes like RS (red) and 10B (blue)] could bind to the cells and then absorbed inside them. After intracellular compartmentation the dye could be eliminated. It was proposed that some proteins could play a role considering that such dyes are also known to bind to proteinaceous materials (Sahoo and Gupta 2005). In addition, the presence of an intact membrane improved the binding for most dyes. Thus, membrane proteins, intracellular compartments and metabolic abilities may have an impact on dye binding and elimination, leading to different scenarios observed here.

\section{Bioplastic production by sludge microflora}

Industrial waste like Kraft paper mill sludge may represent a potential source of feedstock used for bioplastic (PHA) production (Priest 1977; Satoh et al. 1999). Twenty-one of the isolated strains produced PHA as determined by staining with Sudan black B and Nile blue A (Fig. 3), and the best producers included Klebsiella, Bacillus, Paenibacillus, Citrobacter, Serratia, Pseudoxanthomonas and Aeromonas (Table 4). Ten bacterial strains did not grow under our test conditions (PD agar, $\mathrm{pH} 7.0$ and $37^{\circ} \mathrm{C}$ ) or produce any PHA (Table 4). Among all strains, those within the genera Bacillus and Paenibacillus showed the greatest degree of staining and may hold the best potential for production of PHA. Klebsiella is also known to produce PHA (Bandounas et al. 2011) and unlike the latter species does not form spores which could potentially make the extraction of intracellular PHA easier (Verlinden et al. 2007). As far as we are

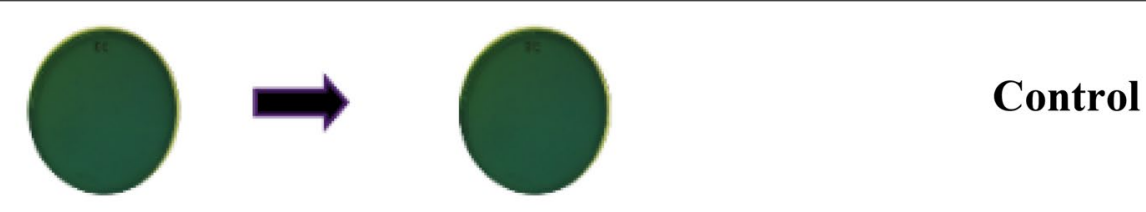

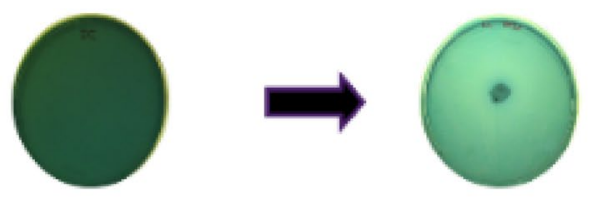
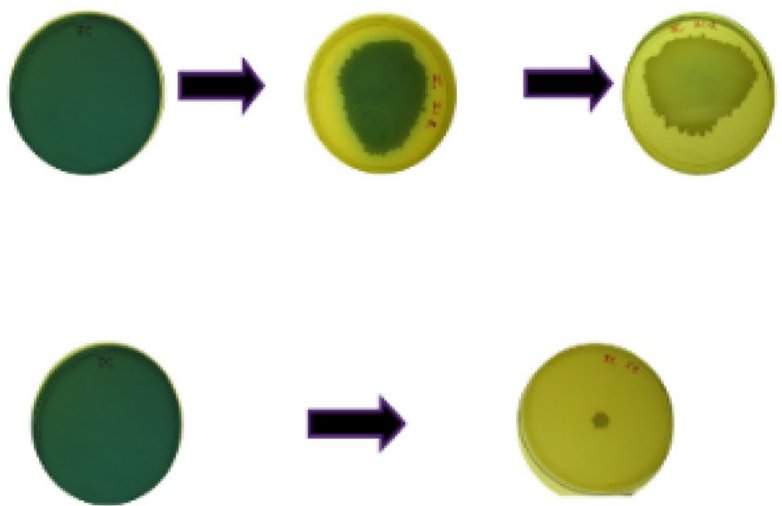

Fig. 2 Mechanisms of bacterial degradation of dye-containing plates

\section{Dye internal absorption}

\section{Dye absorption and internal degradation}

\section{Dye extracellular degradation}



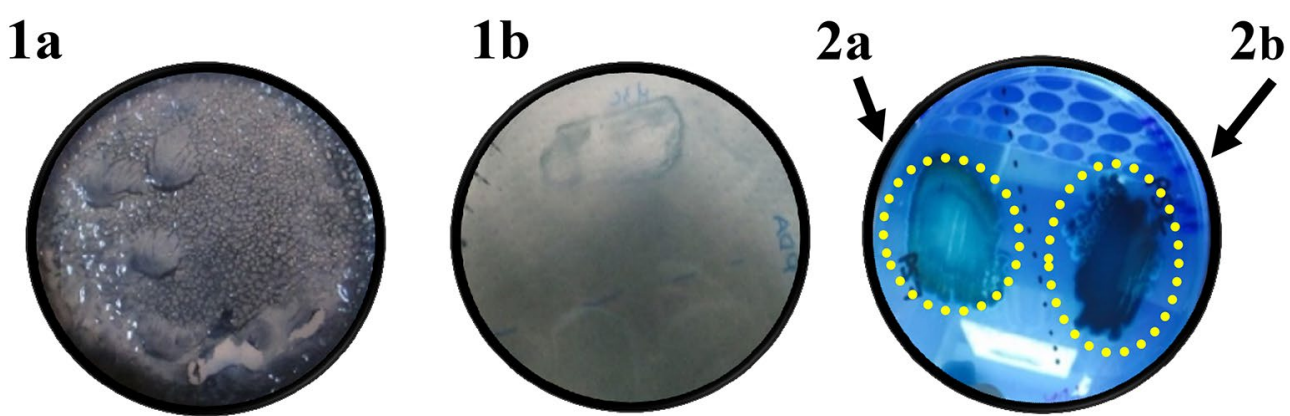

Fig. 3 Detection of bacteria producing PHA after Sudan Black B $(\mathbf{1} \mathbf{a}, \mathbf{1} \mathbf{b})$ and Nile blue A (2a, $\mathbf{2} \mathbf{b})$ staining. 1a PHA positive bacteria revealed with Sudan Black B staining. 1b PHA negative bacteria revealed with Sudan Black B staining. 2a PHA negative with Nile blue staining. 2b PHA positive with Nile blue staining

aware, B. amyloliquefaciens PS1 is the first strain of this species shown to produce PHA.

\section{Conclusion}

Bacteria represent an almost inexhaustible source for different industrial enzymes and offer advantages over other sources due to their rapid growth, moderate production costs, breath of enzyme complexity, and biodiversity. Here, we have examined the readily cultivable bacterial community contained in Kraft paper mill sludge and assessed the potential of theses isolates for industrial enzymatic applications. Microbial diversity and enzyme secretion was partially dependent on the sludge composition, where certain genera were found to be specific to the type of sludge sampled. For example Serratia and Raoultella species were found only in MS, whereas species of Rahnella only in IS. Press sludge (PS) hosted the most diverse bacterial community, with many of these isolates tolerating extremes in both temperature and $\mathrm{pH}$ conditions ( $\mathrm{pH}$ 12). In addition, PS strains also expressed the largest number of hydrolytic and ligninolytic enzymatic activities, a possible consequence of the dense and highly complex composition of PS sludge. Similarly, the bacterial community found in machine sludge (MS) was also quite diverse, although these isolates were devoid of xylanase activity, which may reflect the scarcity of xylan fibers in this type of sludge. A diverse range of Bacillus species encompassing a rich variety of enzymatic activities were associated with the four sludge samples used in this study. Most sludge types contained strains with ligninolytic activities, and the ability to decolourize lignin-mimicking dyes. Many of the isolated strains also grew on media containing Kraft pulping liquor as the sole carbon source. Regardless of the large difference in sludge composition, all strains had the ability to thrive in the presence of lignin or dyes mimicking lignin, indicating that this ability is fundamental for survival in such an environment. Finally, this study clearly demonstrates that bacteria found in a Kraft paper mill have a significant potential for use in industrial applications including bioplastics, stain control and bioremediation.

\section{Additional file}

Additional file 1: Table S1. Morphological characterization of bacterial strains screened from different paper mill sludges. Table S2. Growth temperature and $\mathrm{pH}$ of bacterial strains isolated from the paper mill sludges.

\section{Authors' contributions}

MG, FM and MB have planned sampling strategy and experimental work. MG and FM have sampled and manage strains reported here. Characterisation was performed by MG Initial draft was prepared by MG and edited by FM and MB who performed final corrections leading to submitted manuscript. All authors read and approved the final manuscript.

\section{Author details}

${ }^{1}$ CRML, Centre de Recherche sur les Matériaux Lignocellulosiques, Université du Québec à Trois-Rivières, C.P. 500, Trois-Rivières, QC G9A 5H7, Canada. ${ }^{2}$ PROTEO, Université Laval, Quebec, QC G1V 4G2, Canada.

\section{Acknowledgements}

Our heartfelt thanks to Dr. Martin Kalmokoff for his generous help in editing this manuscript. MB acknowledges financial support from NSERC (CRDPJ 44514), CRIBIQ and Buckman North America. MG was supported by a scholarship from Proteo.

\section{Competing interests}

The authors declare that they have no competing interests.

Received: 1 June 2016 Accepted: 24 August 2016

Published online: 06 September 2016

\section{References}

Abhay R, Chandra R, Mohan M, Krishna R, Hemant JP, Atya K (2007) Biodegradation of kraft lignin by a newly isolated bacterial strain Aneurinibacillus aneurinilyticus from the sludge of a pulp paper mill. World J Microbiol Biotechnol 23:793-799. doi:10.1007/s1 1274-006-9299-x

Adrio JL, Demain AL (2005) Microbial cells and enzymes. A century of progress. Methods Biotechnol Microb Enzyme Biotransform 17:1-27 
Ai T, Jiang Z, Qiu Y, Dong X, Cui S (2003) New technology advance in soda recovery of pulp black liquors. Hubei Papermak 4:36-39

Apparao U, Krishnaswamy VG (2015) Production of polyhydroxyalkanoate (PHA) by a moderately halotolerant bacterium Klebsiella pneumonia isolated from rubber plantation area. Int J Environ Bioremed Biodegrad 3:54-61. doi:10.12691/ijebb-3-2-3

Arora DS, Sandhu DK (1985) Laccase production and wood degradation by a white-rot fungus Daedalea flavida. Enzyme Microb Technol 7:405-408

Bandounas L, Wierckx NJP, Johannes H, Harald JR (2011) Isolation and characterization of novel bacterial strains exhibiting ligninolytic potential. BMC Biotechnol 11:1472-6750. doi:10.1186/1472-6750-11-94

Barr DP, Steven D (1994) Mechanisms white rot fungi use to degrade pollutants. Aust Environ Sci Technol 28:78A-87A. doi:10.1021/es00051a002

Beauchamp CJ, Beaunoir AMS, Beaulieu C, Chalifour FP (2006) Confirmation of $E$. coli among other thermotolerant coliform bacteria in paper mill effluents, wood chips screening rejects and paper sludges. Water Res 40:2452-2462

Bengtsson S, Werker A, Christensson M, Welander T (2006) Production of polyhydroxyalkanoates by activated sludge treating a paper mill wastewater. Bioresour Technol 99:509-516

Blanca EB, Carlos C, Marquez MC (2007) Biodegradation of azo dyes by bacteria inoculated on solid media. Dyes Pigments 75:73-81

Brahimi Horn MC, Lim KK, Liany SL, Mou DG (1992) Binding of textile azo dyes by Mirothecium verrucaria-Orange II, 10B (blue) and RS (red) azo dye uptake for textile wastewater decolorization. J Ind Microbiol 10:31-36

Braunegg G, Bona R, Koller M (2004) Sustainable polymer production. Polym Plast Technol 1:1779-1793

CANMET Energy Technology Centre (2005) Pulp and paper sludge to energy preliminary assessment of technologies, Canada

Chandra R, Abhishek A, Sankhwar M (2011) Bacterial decolorization and detoxification of black liquor from rayon grade pulp manufacturing paper industry and detection of their metabolic products. Biores Technol 102:6429-6436

Charbonneau DM, Meddeb-Mouelhi F, Boissinot M, Sirois M, Beauregard M (2011) Identification of thermophilic bacterial strains producing thermotolerant hydrolytic enzymes from manure compost. Indian J Microbiol 52:41-47. doi:10.1007/s12088-011-0156-8

Chen GQ (2009) A microbial polyhydroxyalkanoates (PHA) based bio- and materials industry. Chem Soc Rev 38:2434-2446

Chiellini C, lannelli R, Lena R, Gullo M, Petroni G (2014) Bacteria characterization in paper mill white water. Bioressources 9:2541-2559

Crecchio C, Ruggiero P, Pizzigallo MDR (1995) Polyphenoloxidases immobilized in organic gels, properties and applications in the detoxification of aromatic compounds. Biotechnol Bioeng 48:585-591

D'Souza T, Sharma D, Raghukumar C (2009) A thermostable metal-tolerant laccase with bioremediation potential from a marine-derived fungus. Mar Biotechnol 11:725-737

Daizong C, Guofang L, Min Z, Song H (2014) Decolourization of azo dyes by a newly isolated Klebsiella sp. strain Y3, and effects of various factors on biodegradation. Biotechnol Biotechnol Equip 28:478-486. doi:10.1080/13 102818.2014 .926053

Demain AL, Adrio JL (2008) Contributions of microorganisms to industrial biology. Mol Biotechnol 38:41-55

Desjardins E, Beaulieu C (2003) Identification of bacteria contaminating pulp and a paper machine in a Canadian paper mill. J Ind Microb Biotechnol 30:141-145

Eriksson KE, KirkTK (1994) Biopulping: an overview of developments in an environmentally safe paper making technology. FEMS Microbiol Rev 13:351-364. doi:10.1111/j.1574-6976.1994.tb00054.x

Fariha H, Aamer AS, Sundus J, Abdul H (2010) Enzymes used in detergents: lipases. Afr J Biotechnol 9:4836-4844

Fisher AK, Freedman BG, Bevan DR, Sengera RS (2014) A review of metabolic and enzymatic engineering strategies for designing and optimizing performance of microbial cell factorie. Comput Struct Biotechnol J 11:91-99. doi:10.1016/j.csbj.2014.08.010

Gomaa EZ (2014) Production of polyhydroxyalkanoates (PHAs) by Bacillus subtilis and Escherichia coli grown on cane molasses fortified with ethanol. Braz Arch Biol Technol 57:145-154

Gupta R, Gupta N, Rathi P (2004) Bacterial lipases: an overview of production, purification and biochemical properties. Appl Microbiol Biotechnol 64:763-781
Hardiman E, Gibbs M, Reeves R, Bergquist P (2010) Directed evolution of a thermophilic $\beta$-glucosidase for cellulosic bioethanol production. Appl Biochem Biotechnol 161:301-312. doi:10.1007/s12010-009-8794-6

Harju-Jeanty P, Vaatanen P (1984) Detrimental microorganism in the paper and cardboard mills. Pap Puu 3:245-259

Hofrichter M (2002) Review: lignin conversion by manganese peroxidase (MnP). Enzyme Microb Technol 30:454-466

Houde A, Kademi A, Leblanc D (2004) Lipases and their industrial applications: an overview. Appl Biochem Biotechnol 118:155-170

Huang G, Jeffrey XS, Langrish TAG (2007) A new pulping process for wheat straw to reduce problems with the discharge of black liquor. Bioresour Technol 98:2829-2835

Integrated Pollution Prevention and Control (IPPC) (2001) Reference document on best available techniques in the pulp and paper industry. European Commission. http://eippcb.jrc.ec.europa.eu/reference/BREF/ ppm_bref_1201.pdf

Jaeger KE, Reetz TM (1998) Microbial lipases form versatile tools for biotechnology. Trends Biotechnol 16:396-403

Kämpfer P, Falsen E, Lodders N, Martin K, Kassmannhuber J, Busse HJ (2012) Paenibacillus chartarius sp. nov., isolated from a paper mill. Int J Syst Evolut Microbiol 62:1342-1347. doi:10.1099/ijs.0.035154-0

Karn SK, Chakrabarty SK, Reddy MS (2010) Pentachlorophenol degradation by Pseudomonas stutzeri CL7 in the secondary sludge of pulp and paper mill. J Environ Sci 22:1608-1612

Karn SK, Kumar P, Pan X (2013) Extraction of lipase and protease and characterization of activated sludge from pulp and paper industry. Prep Biochem Biotechnol 43:152-162. doi:10.1080/10826068.2012.712589

Kiiskinen LL, Ratto M, Kruus K (2004) Screening for novel laccaseproducing microbes. J Appl Microbiol 97:640-646. doi:10.111 1/j.1365-2672.2004.02348.x43

Kirk O, Borchert TV, Fuglsang CC (2002) Industrial enzyme applications. Curr Opin Biotechnol 13:345-351

Kitamura S, Doi Y (1994) Staining method of poly (3-hydroxyalkanoic acids) producing bacteria by Nile blue. Biotechnol Tech 8:345-350

Kubicek CP, Mach RL, Peterbauer CK, Lorito M (2001) Trichoderma: from genes to biocontrol. J Plant Pathol 83:11-23

Kubicek CP, Mikus M, Schuster A, Schmoll M, Seiboth B (2009) Metabolic engineering strategies for the improvement of cellulase production by Hypocrea jecorina. Biotechnol Biofuels 2:1754-6834

Kuhad RC, Singh A, Eriksson KEL (1997) Microorganisms and enzymes involved in the degradation of plant fiber cell walls. Adv Biochem Eng Biotechnol $57: 47-125$

Kumar A, Harrison PM, Cheung KH, Lan N, Echols N, Bertone P et al (2002) An integrated approach for finding overlooked genes in yeast. Nat Biotechnol 20:58-63

Kumar R, Singh S, Singh OV (2008) Bioconversion of lignocellulosic biomass: Biochemical and molecular perspectives. I Ind Microbiol Biotechnol 35:377-391

Liu L, Yang H, Shin HD, Chen RR, Li J, Du G, Chen J (2013) How to achieve high-level expression of microbial enzymes: strategies and perspectives. Bioengineered. doi:10.4161/bioe.24761

Maki ML, Broere M, Leung KT, Qin W (2011) Characterization of some efficient cellulase producing bacteria isolated from paper mill sludges and organic fertilizers. Int J Biochem Mol Biol 2:146-154

Martin CM (1988) Identification and implications of troublesome slime-forming bacteria found in paper mills. TAPPI paper-makers conference. TAPPI Press, Atlanta, pp 91-95

Martínez MJ, Gutiérrez A, del Río JC (2005) Biodegradation of lignocellulosics: microbial, chemical, and enzymatic aspects of the fungal attack of lignin. Int Microbiol 8:195-204

Mathews SL, Ayoub AS, Pawlak J, Grunden AM (2013) Methods for facilitating microbial growth on pulp mill waste streams and characterization of the biodegradation potential of cultured microbes. J Vis Exp 82:51373. doi:10.3791/51373

Meddeb-Mouelhi F, Moisan JK, Beauregard M (2015) Characterization of bacteria community isolated from wood decay. Br Biotechnol J 10:2231-2927

Naheed N, Jamil N (2014) Optimization of biodegradable plastic production on sugar cane molasses in Enterobacter sp. SEL2. Braz J Microbiol 45:417-426

Nathalie B, Bopha Y, Lefebvre R (2015) From organic pollutants to bioplastics: insights into the bioremediation of aromatic compounds by Cupriavidus necator. New Biotechnol 32:1871-6784. doi:10.1016/j.nbt.2014.09.003 
Negrão DR, Sain M, Alcides LL, Sameni J, Jeng R, Jesus JPF, Regina T, Monteiro R (2015) Fragmentation of lignin from Organosolv Black liquor by White rot fungi, bioresources. BioResources 10:1553-1573

Niemelä SI, Väätänen P (1982) Survival in lake water of Klebsiella pneumoniae discharged by a paper mill. Appl Environ Microbiol 44:264-269

Nigam PS (2013) Microbial enzymes with special characteristics for biotechnological applications. Biomolecules 3:597-611. doi:10.3390/biom3030597

Nigam PS, Pandey A (2009a) Biotechnology for agro-industrial residues utilisation: utilisation of agro-residues. Springer, Heidelberg. ISBN 978-1-4020-9941-0

Nigam PS, Pandey A (2009) Biotechnology for agro-industrial residues utilisation: utilisation of agro-residues. Springer, Heidelberg. ISBN 978-1-40209941-0. http://public.eblib.com/EBLPublic/PublicView.do?ptilD=450886

Nigam P, Singh D (1995) Enzyme and microbial systems involved in starch processing. Enzyme Microb Technol 17:770-778. doi:10.1016/0141-0229(94)00003-A

Nigam VK, Singhal P, Vidyarthi AS, Mohan MK, Ghosh P (2013) Studies on keratinolytic activity of alkaline proteases from halophilic bacteria. Int J Pharm Biol Sci 4:389-399

Oliveira PL, Teixeira Duarte MC, Ponezi AN, Durrant RL (2009) Purification and Partial characterization of manganese peroxidase from Bacillus pumilus and Paenibacillus sp. Braz J Microbiol 40:818-826

Orth AB, Royse DJ, Tien M (1993) Ubiquity of lignin degrading peroxidases among various wood degrading fungi. Appl Environ Microbiol 59:4017-4023

Oyadomari M, Shinohara H, Johjima T, Wariishi H, Tanaka H (2003) Electrochemical characterization of lignin peroxidase from the white-rot basidiomycete Phanerochaete chrysosporium. J Mol Catal B Enzyme 21:291-297

Pandey A, Benjamin S, Soccol CR, Nigam P, Krieger N, Soccol VT (1999) The realm of microbial lipases in biotechnology. Biotechnol Appl Biochem 2:119-131

Patil KJ, Chopda MZ, Mahajan RT (2011) Lipase biodiversity. Indian J Sci Technol 4:971-982

Paye JMD, Lynd L, Guseva A, Hammer SK, Gjersing E, Davis MF, Davison BH, Olstad J, Donohoe BS, Nguyen TY, Wyman CE, Pattathil S, Hahn MG (2015) Biological lignocellulose solubilisation: comparative evaluation of biocatalysts and enhancement via cotreatment. Biotechnol Biofuels. doi:10.1186/s13068-015-0412-y

Pervaiz M, Sai M (2012) Protein extraction from secondary sludge of paper mill wastewater and its utilization as a wood adhesive. BioResources 6:961-970

Priest FG (1977) Extracellular enzyme synthesis in the genus Bacillus. Bacteriol Rev 41:711-753

Raj A, Kumar S, Kumar Singh S, Kumar M (2013) Characterization of a new Providencia sp. strain $\mathrm{X} 1$ producing multiple xylanases on wheat bran. Sci World J. doi:10.1155/2013/386769

Rehman S, Jamil N, Hasnain S (2007) Screening of different contaminated environments for polyhydroxyalkanoates producing bacterial strain. Biologia 62:650-656
Rieger PG, Meier HM, Gerle M, Vogt U, Groth T, Knackmuss HJ (2002) Xenobiotics in the environment: present and future strategies to obviate the problem of biological persistence. J Biotechnol 94:101-123

Sahoo DK, Gupta R (2005) Evaluation of ligninolytic microorganisms for efficient decolorization of a small pulp and paper mill effluent. Process Biochem 40:1573-1578

Satoh H, Mino T, Matsuo T (1999) PHA production by activated sludge. Int J Biol Macromol 25:105-109

Schallmey M, Singh A, Ward OP (2004) Developments in the use of Bacillus species for industrial production. Rev Can Microbiol 50:1-17

Sharyo MHHMYH (1993) The recent progress and general status of the lipase pitch control technology in Japan. Jpn Tappi J 47:41-51

Singh NP, Prabhu KA (1986) Cellulase and ligninase production by basidiomycete culture in solid-state fermentation. Microbial enzymes with special characteristics for biotechnological applications. Biomolecules 2013:3597-3611

Singh M, Patel SKS, Kalia VC (2009) Bacillus subtilis as potential producer for polyhydroxyalkanoates. Microb Cell Facties 8:38. doi:10.1186/1475-2859-8-38

Vaisanen OM, Mwaisumo NJ, Salkinoja-Salonen MS (1991) Differentiation of dairy strains of the Bacillus cereus group by phage typing, minimum growth temperature, and fatty acid analysis. J Appl Microbiol 70:315-324

Van Dyke Y (2004) Practical applications of protease enzymes in paper. The Book and Paper Group Annual 23:93 http://cool.conservation-us.org/ coolaic/sg/bpg/annual/v23/bp23-16.pdf. Accessed 20th April 2016

Verlinden RAJ, Hill DJ, Kenward MA, Williams CD, Khanna IR, Radecka I (2007) Bacterial synthesis of biodegradable polyhydroxyalkanoates. J Appl Microbiol 102(6):1364-5072. doi:10.1111/j.1365-2672.2007.03335.x

Wang WL, Kang L, Lee YY (2010) Production of cellulase from kraft paper mill sludge by Trichoderma reesei rut C-30. Biochem Biotechnol 161:382-394. doi:10.1007/s12010-009-8863-x

Wesenberg D, Kyriakides I, Agathos SN (2003) White-rot fungi and their enzymes for the treatment of industrial dye effluents. Biotechnol Adv 22:161-187

Wongwilaiwalin S, Rattanachomsri U, Laothanachareon T, Eurwilaichitr L, Igarashi Y, Champreda V (2010) Analysis of a thermophilic lignocellulose degrading microbial consortium and multi-species lignocellulolytic enzyme system. Enzyme Microb Technol 47:283-290

Woo HL, Utturkar S, Klingeman D, Simmons BA, DeAngelis KM, Brown SD, Hazen TC (2014) Draft genome sequence of the lignin-degrading Burkholderia sp. strain LIG30, isolated from wet tropical forest soil. Genome Announc 2:637. doi:10.1128/genomeA.00637-14

Global Markets for Enzymes in Industrial Applications. http://www.reportlinker com/p0870778/Global-Markets-for-Enzymes-in-Industrial-Applications. html

Zhou S, Ingram LO (2000) Synergistic hydrolysis of carboxymethyl cellulose and acid-swollen cellulose by two endoglucanases (CelZ and CelY) from Erwinia chrysanthemi. J Bacteriol 182:5676-5682

\section{Submit your manuscript to a SpringerOpen ${ }^{\circ}$ journal and benefit from:}

- Convenient online submission

- Rigorous peer review

- Immediate publication on acceptance

- Open access: articles freely available online

- High visibility within the field

- Retaining the copyright to your article

Submit your next manuscript at $\mathbf{s p r i n g e r o p e n . c o m ~}$ 